\title{
Fungal survival under temperature stress: A proteomic perspective
}

\author{
Nurlizah Abu Bakar ${ }^{1,2}$, Saiful Anuar Karsani ${ }^{3}$, Siti Aisyah Alias ${ }^{\text {Corresp. 1, } 2}$ \\ 1 Institute of Ocean and Earth Sciences, Universiti Malaya, Kuala Lumpur, Malaysia \\ 2 National Antarctic Research Centre, Universiti Malaya, Kuala Lumpur, Malaysia \\ 3 Institute of Biological Sciences, Faculty of Science, Universiti Malaya, Kuala Lumpur, Malaysia \\ Corresponding Author: Siti Aisyah Alias \\ Email address: saa@um.edu.my
}

Background. Increases in knowledge of climate change generally, and its impact on agricultural industries specifically, has led to a greater research effort aimed at improving understanding of the role of fungi in various fields. Fungi play a key role in soil ecosystems as the primary agent of decomposition, recycling of organic nutrients. Fungi also include important pathogens of plants, insects, bacteria, domestic animals and humans, thus highlighting their importance in many contexts. Temperature directly affects fungal growth and protein dynamics, which ultimately will cascade through to affect crop performance. To study changes in the global protein complement of fungi, proteomic approaches have been used to examine links between temperature stress and fungal proteomic profiles.

Survey methodology and objectives. A traditional rather than a systematic review approach was taken to focus on fungal responses to temperature stress elucidated using proteomic approaches. The effects of temperature stress on fungal metabolic pathways and, in particular, heat shock proteins (HSPs) are discussed. The objective of this review is to provide an overview of the effects of temperature stress on fungal proteomes.

Concluding remarks. Elucidating fungal proteomic response under temperature stress is useful in the context of increasing understanding of fungal sensitivity and resilience to the challenges posed by contemporary climate change processes. Although useful, a more thorough work is needed such as combining data from multiple -omics platforms in order to develop deeper understanding of the factor influencing and controlling cell physiology. This information can be beneficial to identify potential biomarkers for monitoring environmental changes in soil, including the agricultural ecosystems vital to human society and economy. 


\section{Fungal Survival under Temperature Stress: a Proteomic Perspective}

2 Nurlizah Abu Bakar ${ }^{1,2}$, Saiful Anuar Karsani ${ }^{3}$, Siti Aisyah Alias ${ }^{1,2}$

3

4

5

${ }^{1}$ Institute of Ocean and Earth Sciences, Universiti Malaya, Kuala Lumpur, Malaysia.

${ }^{2}$ National Antarctic Research Centre, Universiti Malaya, Kuala Lumpur, Malaysia

${ }^{3}$ Institute of Biological Sciences, Faculty of Science, Universiti Malaya, Kuala Lumpur, Malaysia.

Corresponding Author:

Siti Aisyah Alias ${ }^{1}$

C308, IPS Building, University Malaya, Kuala Lumpur, 50603, Malaysia

Email address: saa@um.edu.my

\section{Abstract}

Background. Increases in knowledge of climate change generally, and its impact on agricultural industries specifically, has led to a greater research effort aimed at improving understanding of the role of fungi in various fields. Fungi play a key role in soil ecosystems as the primary agent of decomposition, recycling of organic nutrients. Fungi also include important pathogens of plants, insects, bacteria, domestic animals and humans, thus highlighting their importance in many contexts. Temperature directly affects fungal growth and protein dynamics, which ultimately will cascade through to affect crop performance. To study changes in the global protein complement of fungi, proteomic approaches have been used to examine links between temperature stress and fungal proteomic profiles.

Survey methodology and objectives. A traditional rather than a systematic review approach was taken to focus on fungal responses to temperature stress elucidated using proteomic approaches. The effects of temperature stress on fungal metabolic pathways and, in particular, heat shock proteins (HSPs) are discussed. The objective of this review is to provide an overview of the effects of temperature stress on fungal proteomes.

Concluding remarks. Elucidating fungal proteomic response under temperature stress is useful in the context of increasing understanding of fungal sensitivity and resilience to the challenges posed by contemporary climate change processes. Although useful, a more thorough work is needed such as combining data from multiple -omics platforms in order to develop deeper understanding of the factor influencing and controlling cell physiology. This information can be beneficial to identify potential biomarkers for monitoring environmental changes in soil, including the agricultural ecosystems vital to human society and economy.

\section{Introduction}

Global warming and associated environmental changes impact living organisms in various ways. The recent Intergovernmental Panel on Climate Change (IPCC 2018) Special Report: Global 
41 Warming of $1.5^{\circ} \mathrm{C}$, predicted that extreme hot day events in mid-latitudes may warm by up to

42 43

44

45

46

47

48

49

50

51

52

53

54

55

56

57

58

59

60

61

62

63

64

65

66

67

68

69

70

71

72

73

74

75

76

77

78

79 $\sim 3^{\circ} \mathrm{C}$ with global warming of $1.5^{\circ} \mathrm{C}$. It is also predicted that extreme night-time low temperatures at high latitudes warm by $\sim 4.5^{\circ} \mathrm{C}$ (IPCC 2018). If current trends persist, global ice loss will continue, the temperate regions will experience more frequent extreme high and low temperature events (Francis \& Skific 2015), and different parts of the tropics will experience longer drought and wet seasons (Overland et al. 2015). This can potentially lead to the breakdown of ecosystem structure and functions, making them yet more sensitive to future climate changes. There have already been some drastic changes in rainfall patterns and patterns of temperature variation (Kundzewicz et al. 2005), alreadyleading to significant reductions in land surface area suitable for crop cultivation (Lesk et al. 2016). Several reviews have addressed research approaches for the development of improved crops in low-quality soils, and of soil management systems to improve resilience to current climate change challenges (Fan et al. 2012; Rao et al. 2016b; Zhang et al. 2013). Major outcomes of these include the use of better-adapted phenotypes (Rao et al. 2016a; Simova-Stoilova et al. 2016), integrated soil-crop system management (Zhang et al. 2013), and maintenance of functional diversity in the soil fungal community by retaining a capacity for symbiosis-driven recycling of organic nutrient pools (Kyaschenko et al. 2017).

The fundamental importance of including mycological studies in efforts to sustain agricultural industries and underpin economic growth is recognised in the European Union's common research 2014-2020 program, known as Horizon 2020 (Lange et al. 2012). Fungi are generally the most important agent of primary decomposition and nutrient cycling in soil microbial communities (A'Bear et al. 2014b). In boreal forest management and long-term forest production, the functional diversity of the ectomycorrhizal fungal community plays an important role in facilitating symbiosis-driven recycling of organic nutrient pools (Kyaschenko et al. 2017). The key role of fungi identified in such studies highlights the importance of understanding fungal responses to temperature stress. Active fungi initiate stress tolerance strategies at the molecular level and this can be observed in the physiological changes they undergo. Under temperature stress conditions, the tertiary structure of molecules such as enzymes and other functional proteins can be damaged; they will not function properly and may be degraded. Fungi may produce heat or cold marker molecules such as heat shock proteins and chaperones to assist in the repair of functional structure (Bai et al. 2015; Tiwari et al. 2015). There will be substantial physiological changes that can be understood from their molecular-level responses. Such physiological changes can include the production of anti-freeze proteins coating the cell wall (Bagwell \& Ricker 2019), the production of extracellular hydrolases such as chitinolytic enzymes (Fenice 2016), and increased production of heat shock proteins to minimize protein misfolding (Kroll et al. 2014; Miteva-Staleva et al. 2017). Such stress tolerance strategies improve cell and organism survival in stressed and sub-optimal environments (Williams et al. 2011).

Peer] reviewing PDF | (2020:02:46059:2:0:NEW 19 Oct 2020) 
80 Changes in protein contents generate a signature that can be identified and characterized.

81 Potentially, these signatures can help understand organismal responses to stress, and be used as

82 biomarkers for monitoring environmental changes and their effects on the ecosystem.

83 Comparative analyses of fungal proteomic profiles can be used to understand changes in protein

84 abundance that may serve as important biomarkers of temperature stress (Kroll et al. 2014). To

85 date, most studies of fungal proteomic response towards temperature stress have been conducted

86 on pathogenic species. Examples include the black yeast, Exophiala dermatitidis, that can cause

87 serious skin infections in humans (Tesei et al. 2015); Aspergillus flavus, a producer of lethal

88 aflatoxins (Bai et al. 2015; Delgado et al. 2015); Aspergillus fumigatus, a thermo-tolerant human

89 pathogen (Albrecht et al. 2010); Ustilago maydis, a basidiomycete that causes corn smut disease

90 (Salmeron-Santiago et al. 2011); and Metarhizium acridum, an entomopathogenic species that

91 can be used as an alternative to chemical insecticides (Barros et al. 2010). Several studies have

92 also been carried out on extremophiles such as Cryomyces antarcticus in order to understand

93 extreme stress tolerance from the proteomic perspective (Isola et al. 2011; Tesei et al. 2012;

94 Zakharova et al. 2014).

95

96

97

98

99

100

101

102

103

104

105

106

107

108

109

110

111

112

113

114

115

116

117

118

119

In the last 10 years an increasing number of studies have analysed fungal temperature stress responses using proteomic approaches (Albrecht et al. 2010; Bai et al. 2015; Salmeron-Santiago et al. 2011; Tesei et al. 2015; Zakharova et al. 2014). Some have also used 'multi-omic' approaches that combine the simultaneous analysis of different molecules (proteins, mRNA, metabolites) to better understand complex biological responses (Bai et al. 2015; Su et al. 2016). Since the late 1990s, proteomic methodologies and technologies have evolved from an approach that relied on two-dimensional gel electrophoresis to gel-free analyses. The protein extraction method is a fundamentally important stage in any proteomic analysis. Optimisation of protein extraction is key in maximising yield and resolution, followed by the selection of proteomic profiling methods (Bianco \& Perrotta 2015; Daim et al. 2015; Isola et al. 2011). Label-free or labelled proteomic approaches, such as isotope and fluorescent labelling, are now used extensively because of their many advantages and provide useful information on differential expression of proteins in complex biological samples (Fricker 2018). However, proteomic remains a very costly field, and interpreting the data obtained requires advanced knowledge of the entire technical process involved, as well as understanding of appropriate statistical principles for estimation and inference (Karpievitch et al. 2010).

\section{Survey methodology and objective}

This review was developed based on research article journals published between 2008 and 2020, indexed in the Web of Science Core Collection and Scopus, Elsevier databases. We focus on studies of fungal response towards temperature stress elucidated using proteomic approaches. The effects of temperature stress (high and low) on metabolic pathways and HSPs specifically are a primary focus because, these two components are crucial in energy regulation and protein

PeerJ reviewing PDF | (2020:02:46059:2:0:NEW 19 Oct 2020) 
120

121

122

123

124

125

126

127

128

129

130

131

132

133

134

135

136

137

138

139

140

141

142

143

144

145

146

147

148

149

150

151

152

153

154

155

156

157

158

159

turnover, and hence for cell survival. This review provides an overview on the effects of temperature stress, on fungal proteomes and the implications this has for fungal responses within the ecosystem to current climate change challenges. The majority of the identified literature documents studies of filamentous fungi, although there are exceptions studying other groups, in particular the microcolonial rock-inhabiting fungus $C$. antarcticus and the black yeast $E$. dermatitidis.

\section{High temperature stress}

In general, definitions of high temperature stress have primarily been made based on the optimum growth temperature $\left(T_{\mathrm{opt}}\right)$ and maximum growth temperature $\left(T_{\max }\right)$ (Su et al. 2016; Tesei et al. 2012). However, this is not always the case. For example, in the study of pathogenic fungi, experimental temperature selection is often based on the host's body temperature (Tesei et al. 2015). Temperature can also be selected based on the induction or optimisation of mycotoxin production (Bai et al. 2015; Salmeron-Santiago et al. 2011). Deviations from the optimum temperature are expected to trigger a response at the molecular level, with the fungal proteome altering to prevent damage to the cell. Another important parameter in high temperature stress studies is the total duration or interval of heat exposure. Shorter exposures of seconds or minutes can lead to different proteomic expression compared to longer, or repeat, exposures (Albrecht et al. 2010; Tesei et al. 2015). This is because native proteins take time to undergo the processes of denaturing, unfolding or refolding, or eventually to be degraded under high temperature conditions (Aragno 1981). There are two important stages in understanding the impact of high temperature stress on cells: the onset of any stress response, and its upper thermal limit. Together, these often give an indication of specific temperature stress response pathways. With an increase in environmental temperature, a higher metabolic rate is generally anticipated in cells. Thus, heat response pathways will be initiated to utilize the extra energy that is being produced from an increase in metabolic rate, and proteomic profiling can be used to understand the physiological changes taking place (Richter et al. 2010). However, on average, cells are only able to tolerate an increase in temperature of a few degrees above $T_{\text {opt }}$ (Aragno 1981). Further increase in temperature beyond this limit causes irreversible damage and ultimately leads to cell death.

Table 1 summarises significant findings on fungal proteome profiling in response to high temperature stress, including the identification of proteins and suggestion of pathways that are potentially related to the identified proteins. A recent integrated -omics study of Mrakia psychrophila provided insight into the adaptation mechanisms of psychrophilic fungi ( $\mathrm{Su}$ et al. 2016). At $4^{\circ} \mathrm{C}$ and $20^{\circ} \mathrm{C}, M$. psychrophila produced an increased amount of major facilitator superfamily (MFS) proteins that are involved mainly in energy metabolism, compared to the level at $12^{\circ} \mathrm{C}$ (optimal growth temperature range $12^{\circ} \mathrm{C}-15^{\circ} \mathrm{C}$ ). However, heat shock proteins were upregulated only at $20^{\circ} \mathrm{C}$, which likely leads to the activation of the unfolded protein 
160

161

162

163

164

165

166

167

168

169

170

171

172

173

174

175

176

177

178

179

180

181

182

183

184

185

186

187

188

189

190

191

192

193

194

195

196

197

198

199

response (UPR). Consistent with this, at $20^{\circ} \mathrm{C}$, there was a negative correlation between the protein level change and transcript level change. The proteome abundances of another psychrophilic fungus, Friedmanniomyces endolithicus (optimal growth temperature range $10^{\circ} \mathrm{C}$ $15^{\circ} \mathrm{C}$ ), assessed using a classical $2 \mathrm{D}$ gel electrophoresis (non-comparative) approach, showed a reduction from 284 (at $28^{\circ} \mathrm{C}$ ) to 224 (comparison between $15^{\circ} \mathrm{C}$ and $28^{\circ} \mathrm{C}$ ) protein spots (Tesei et al. 2012). The authors hypothesized that, with exposure to high temperature, the basic set of proteins necessary to survive is relatively stable without the help of various chaperones. It is also likely that other non-protein protective metabolites and molecules are involved in the response pathways (Keller 2019).

For human pathogenic fungi, their pathogenic characteristics become significant at body temperature. These have been explored in many species, such as Penicillium marneffei and A. flavus. Gauthier (2017) reviewed the molecular strategies used by thermally dimorphic fungi, focusing on their ability to adapt to core body temperature $\left(37^{\circ} \mathrm{C}\right)$ and transition to yeast morphology for virulence capabilities. These fungi used various strategies, such as upregulation of virulence factors, to promote cell adhesion to host, lysis of macrophages, avert cytokine responses, and impair host immunity. Penicillium marneffei is the only dimorphic species in its genus and forms its secondary cellular development, which is a uninucleate yeast, at $37^{\circ} \mathrm{C}$ (Chandler et al. 2008). Increased levels of RanA expression, a GTP-binding nuclear protein that plays a role in nucleocytoplasmic transport, suggest that there is an additional signalling mechanism involved during phase transition in P. marneffei. Comparative work on extracellular proteomes of $P$. marneffe $i$ in yeast and mycelial phases showed upregulation of glyceraldehyde3-phosphate dehydrogenase (GAPDH) and heat shock protein 60 (HSP60), respectively, that may play an important role in cell-host adherence (Lau et al. 2013). Bai et al. (2015) used an integrated transcriptomic and proteomic approach to study the response towards temperature changes in $A$. flavus, a species whose growth optimum is $37^{\circ} \mathrm{C}$, but that produces highest levels of mycotoxin is at $28^{\circ} \mathrm{C}$. The data obtained showed that a subset of 664 proteins involved in translation-related pathways, metabolic pathways and biosynthesis of secondary metabolites were differentially expressed at the two temperatures. At $28^{\circ} \mathrm{C}$, the expression pattern of proteins and transcripts related to aflatoxin biosynthesis were upregulated, and the authors suggested that change in the aflR transcript level was a better marker for the activation of aflatoxin biosynthesis. However, they also noted that there was a low correlation between overall transcript level and protein concentration in A. flavus, suggesting that the post-transcription modification processes may play a critical role in the regulation of the final protein expression level.

The plant pathogen, U. maydis is a well-studied causative agent for corn smut disease, but there are also reports of Ustilago spp. infections in humans (McNeil \& Palazzi 2012; Teo \& Tay 2006). Under various stress conditions, fungi often accumulate trehalose and initiate trehalose biosynthesis pathways (Al-Bader et al. 2010; Nwaka \& Holzer 1997). In a study of the effect of 
200

201

202

203

204

205

206

207

208

209

210

211

212

213

214

215

216

217

218

219

220

221

222

223

224

225

226

227

228

229

230

231

232

233

234

235

236

237

238

239

temperature stress on $U$. maydis, increased production of 11 proteins, commonly up-regulated in response to osmotic and sorbitol stress, was observed (Salmeron-Santiago et al. 2011). However, there were no changes in the trehalose concentration, thus suggesting that the up-regulated proteins are common proteins in the general stress response of $U$. maydis, non-specific to trehalose metabolism pathways. A more recent review (Perez-Nadales et al. 2014) highlighted the overall mechanisms of pathogenesis and some unifying themes among various fungal model organisms, emphasising the importance of conserved signalling pathways such as the cyclic adenosine monophosphate (cAMP)-dependent protein kinase A and mitogen-activated protein (MAP) kinases, and the central roles of secondary metabolic pathways in a very wide range of pathogenic fungi. However, comparison of the effect of temperature on the pathogenicity of fungal model organisms was not a focus of that study.

Mesophilic fungi, which have $T_{\text {opt }}$ of $25-30^{\circ} \mathrm{C}$, are generally able to tolerate a wider range of temperatures and associated stress, having a relatively wider range of temperature-dependent growth curves (Dix \& Webster 1995). In a non-comparative experiment on three mesophilic fungi (Exophiala jeanselmei, Coniosporium perforans and Penicillium chrysogenum), high temperature exposure led to variation in their proteomic expression patterns (Tesei et al. 2012). Exposure to $40^{\circ} \mathrm{C}$ increased the number of expressed proteins detected in $P$. chrysogenum but decreased those of $E$. jeanselmei and $C$. perforans. - A comparison was also made between species at $40^{\circ} \mathrm{C}$ by selecting $P$. chrysogenum as the reference strain for mesophilic black fungi, which revealed 50 and 62 common protein spots in E. jeanselmei and C. perforans, respectively. The study suggested that there was a lack of a heat-shock protein response in E. jeanselmei and C. perforans. Furthermore, the disappearance of spots from the same $\mathrm{pI}$ and molecular mass range (respectively 5-7 and 30-90 $\mathrm{kDa}$ ) suggested that both strains probably downregulated similar sets of proteins. Tesei et al. (2012) hypothesized that either the basic set of proteins that is important in high temperature exposure is stable without the help of heat-shock proteins or that other non-protein protective metabolites are involved. It is important to understand the limitations of such non-comparative experiments conducted through gel-based methods, where technical variations between replicates are expected. Quantification and identification of protein spots can be a challenge if differences in staining occur between two gels with no normalization. An integrated analysis of transcriptomic and proteomic responses of $A$. fumigatus exposed to high temperature stress improved understanding of the thermotolerant characteristics responsible for the pathogenicity of this fungus (Albrecht et al. 2010). The study identified 91 differentially regulated protein spots representing 64 different proteins using two-dimensional difference gel electrophoresis (2D-DIGE) and tandem mass spectrometry (MS/MS) identification methods. These included a number of previously undescribed putative targets for the heat shock regulator Hsf1, providing evidence for Hsf1-dependent regulation of mannitol biosynthesis, translation, cytoskeletal dynamics, and cell division in A. fumigatus. Albrecht et al. (2010) also demonstrated a negative correlation between protein expression and gene transcription levels in $A$. fumigatus when exposed to supra-optimal temperatures (from $30^{\circ} \mathrm{C}$ to $48^{\circ} \mathrm{C}$ ). The synthesis of most 
240 proteins was delayed by 60 to 90 minutes (medium delay) and up to 105 minutes (strong delay),

241 after gene transcription by exposure to supra-optimal temperatures.

242

243 High temperature exposure causes specific stress response mechanisms to be activated that can

244 be further explored using fungal proteomic profiles. Most fungi respond to high temperature

245 stress by increasing the production of heat-shock proteins and chaperones and initiating

246 alternative metabolic pathways (Albrecht et al. 2010; Bai et al. 2015; Su et al. 2016). However,

247 some species show no significant changes in their proteome profiles, suggesting that the basic set

248 of proteins needed for survival are highly thermotolerant (Tesei et al. 2015; Tesei et al. 2012). It

249 has also been hypothesized that this is explained by the production of secondary metabolites and

250 other non-protein protective metabolites that cannot be determined through proteomic

251 approaches (Zhang et al. 2016). In addition, high temperature stress may induce a negative

252 correlation between gene transcription and protein production in fungal cells due to post-

253 translational modification and the initiation of protein degradation pathways, such as the

254 ubiquitin-mediated protein degradation pathway and spliceosome-mediated decay (SMD)

255 pathway (Albrecht et al. 2010; Bai et al. 2015).

256

257 Low temperature stress

258

259

260

The study of low temperature stress resistance in microorganisms and other organisms has led to many beneficial findings. Proteins, such as cold-adapted enzymes, have been applied in many

261 biotechnology industries such as in the manufacture of food and beverages, detergents, textiles,

262 and in industrial molecular biology (Sarmiento et al. 2015). Research on cold-adapted proteins

263 often involves psychrophilic or psychrotolerant microorganisms from the polar regions or deep

264 oceans (Cavicchioli et al. 2000). Psychrophiles produce cold-adapted proteins with unique

265

266 characteristics that have weak protein interactions, low thermal stability and increased specific activity, in order to achieve higher protein activity and flexibility at low temperatures (Reed et al.

267 2013). Protein structures are modified with subtle changes in the amino acid composition, thus

268

269 remaining functional under extremely cold conditions. Wang et al. (2017) reviewed fungal

270 adaptation to cold stress, providing an overview of life history strategies and highlighting the importance of cold-adapted fungi in the discovery of novel secondary metabolites and enzymes. Studies on fungal proteome profiles in response to low temperature stress are summarised in

272 Table 2.

273

274

In a study of black rock-inhabiting fungi exposed to low temperature stress, their proteomic

275 profiles generally showed an increase in total number of spots, except for P. chrysogenum (Tesei

276 et al. 2012). Friedmanniomyces endolithicus and $C$. perforans proteome profiles exhibited

277 changes in high molecular mass protein spots $(70-170 \mathrm{kDa})$, while that of $E$. jeanselmei showed

278 pattern changes at slightly lower molecular mass (25 - $100 \mathrm{kDa})$. Penicillium chrysogenum

279 exhibited a decrease in total protein spots, interpreted as being due to lower metabolic activity 
280

281

282

283

284

285

286

287

288

289

290

291

292

293

294

295

296

297

298

299

300

301

302

303

304

305

306

307

308

309

310

311

312

313

314

315

316

317

318

319

under cold stress. Exophiala dermatitidis, a mesophilic fungus that is pathogenic in humans, was experimentally exposed to low temperature in order to understand the relationship between its thermotolerance properties and pathogenicity (Tesei et al. 2015). The strain was exposed to $1^{\circ} \mathrm{C}$ (low temperature stress) for one week and comparison was then made with proteome profiles obtained at $37^{\circ} \mathrm{C}$ (optimum temperature for growth) and $45^{\circ} \mathrm{C}$ (high temperature stress). Using 2D-DIGE and a nano-scale liquid-chromatography electrospray-ionisation, tandem mass spectrometry (nLC-ESI-MS/MS), the study showed an average of 1700 protein spots detected in E. dermatitidis. Exposure to low temperature stress led to a reduction in proteins associated with metabolic activity, mostly relating to general carbon metabolism. A large set of proteins involved in energy metabolism pathways were down-regulated, such as malate synthase, malate dehydrogenase, acetyl-coenzyme A synthetase and glyceraldehyde-3-phosphate dehydrogenase. Decreased levels of proteins involved in the response to heat stress such as Hsp70s, elongation factor $1 \alpha$ and Hsp30 might also be related to the reduction in metabolic rate and associated reduced energy consumption. Despite utilising alternative metabolic pathways, E. dermatitidis undergoes downregulation of metabolic pathways under exposure to non-optimal temperatures, resulted in a much slower growth rate. Comparison of the proteome profiles of E. dermatitidis under high and low temperature stress demonstrated the contribution to its success as a pathogen made by regulating the expression of basic thermotolerance proteins and modulating the production of proteins in major metabolic pathways.

Mrakia psychrophila, another psychrophilic yeast, showed a slightly different response to low temperature stress compared to E. dermatitidis, but more similar to other cold-adapted fungi such as Flammulina velutipes (Liu et al. 2017) and Mortierella isabellina (Hu et al. 2016). The responses included desaturation of fatty acids and accumulation of glycerol ( $\mathrm{Su}$ et al. 2016). At $4^{\circ} \mathrm{C}$, two proteins were upregulated (glutamine synthetase, GLNA and MFS transporter protein, MPSY), and four proteins were downregulated (citrate synthase, succinyl co-A ligase, pyruvate decarboxylase and ribosomal protein). Comparative transcriptomic analysis showed that genes involved in ribosome production and energy metabolism were also upregulated at $4{ }^{\circ} \mathrm{C}$.

Proteomic analysis indicated that protein levels were positively correlated with transcription levels in some pathways under low temperature stress, suggesting the upregulation of chaperones and energy metabolism pathways. A study of the white rot fungus, $F$. velutipes, showed a similar change in protein profile in response to short-term and long-term exposure to low temperature (Liu et al. 2017). Of 63 differentially expressed proteins, 31 were upregulated, 24 of which were involved in energy metabolic pathways, amino acid biosynthesis and metabolism, signalling pathways, transport and translation. Four upregulated proteins were involved in energy metabolic pathways such as starch and sucrose metabolism (catalase, glucose-6-phosphate isomerase, trehalase and beta-glucosidase). However, catalase was upregulated only in the short term after exposure to low temperature, and its levels returned to normal after longer exposure to low temperature. Eleven differentially expressed proteins were involved in the biosynthesis of nine amino acids, indicating a role played in cold stress response by modifying nitrogen-containing 
320

321

322

323

324

325

326

327

328

329

330

331

332

333

334

335

336

337

338

339

340

341

342

343

344

345

346

\section{7}

348

349

350

351

352

353

354

355

356

357

358

359

molecule storage. Signalling molecules and processes involved in protein degradation were also upregulated, thus suggesting the importance of these molecules in controlling $F$. velutipes mycelium growth and fruiting body formation under cold stress. Proteomic profiling of $M$. isabellina (a soil fungus involved in many biotechnological applications) under low temperature stress identified 44 differentially expressed proteins under cold stress (Hu et al. 2016). These proteins were mainly involved in the regulation of ATP synthesis (ATP synthase subunit beta, ATP synthase d subunit), glycolytic pathways (fructose-bisphosphate aldolase), protein modification and electron transport (cytochrome c oxidase polypeptide 5B). The responses identified in M. isabellina also supported protein degradation pathways playing an important role in cold stress responses in fungi. Proteins such as HSPs and transitional endoplasmic reticulum ATPase (TER ATPase), that are essential in proteasome pathways, were also upregulated under cold stress.

Integrating the findings of these different studies has led to deeper understanding of coldadaptive mechanisms in fungi. They respond to low temperature stress by modifying their energy metabolic pathways, increasing the production of chaperones to minimise misfolded protein production, and regulating the synthesis of amino acids that are important in nitrogen storage. In contrast with studies of high temperature stress, the overall response of many fungal species indicates that low temperature does not cause irreversible damage to cells, with responses acting by modifying molecular content rather than wholesale transformation of complex protein networks. The huge amount of information that can be generated in fungal proteomic studies examining low temperature stress can be utilised for more specific approaches, for example in process optimization and purification of cold-adapted biomolecules. Future studies on cold adaptation mechanisms in fungi will benefit from a focus on identifying common proteins that act as cold stress biomarkers and exploiting the advantages of cold-adapted proteins in biotechnological applications.

\section{Effects of temperature stress in fungal proteomes}

Fungi respond to temperature stress through regulation of various proteins, that can be visualised using proteomic profiling techniques within the limitations noted above. Changes in fungal proteomes exposed to various temperature stresses (Tables 1,2) demonstrate that many cellular functions are affected, such as the TCA cycle and energy production and metabolism, oxidative phosphorylation, regulation of mitotic activities, cell cycle and division, transcriptional and translational stages of biosynthetic pathways, cell wall and cytoskeleton reorganisation, transport protein remodelling, defence against oxidative and other stresses, and cellular signalling mechanisms. Undeniably, these proteins and their roles in cellular functions are highly significant, with the complex cellular protein network maintained through protein homeostasis (Mühlhofer et al. 2019; O' Neill et al. 2020). It is extremely challenging to identify any specific set of proteins as being the most affected by or vulnerable to temperature stress, or being used as 
360

361

362

363

364

365

366

367

368

369

370

371

372

373

374

375

376

377

378

379

380

381

382

383

384

385

386

387

388

389

390

391

392

393

394

395

396

397

398

399

potential temperature stress biomarkers. Metabolic pathways and HSPs are considered a primary focus and elaborated below. These two components are crucial in energy regulation and protein turnover, and hence for cell survival (Yan et al. 2020). More widely, biosynthesis and regulation of metabolic pathways and HSPs are of importance in many applied fields such as agriculture, food biotechnology and medicine (Ene et al. 2014; Lamoth et al. 2016; Sarmiento et al. 2015).

\section{Effect of temperature stress on metabolic pathways}

Fungal adaptation towards temperature stress involves alterations in the utilisation of many metabolic pathways in trade-offs to compensate for the amount of energy needed or the extra energy to be utilised in delivering the stress response. As temperature increases, the rate of metabolism (of a non-endothermic organism) increases as a purely physical consequence, and then rapidly declines at higher temperatures as the metabolic systems start to fail - eventually leading to cell death. Metabolic regulation is one strategy employed by organisms to adapt to temperature stress, which is controlled by factors such as concentration of substrates, products or allosteric effectors (Clarke 2018; Suarez \& Moyes 2012). Understanding thermal adaptation in fungi requires an overall understanding on the effects of temperature on pathway flux, including such things as the roles and limitations of enzymes involved, concentration of substrates and products, and other protein and non-protein components (Schulte 2015). Advances in proteomic technologies have made it possible to determine many of the proteins involved in the complex network of metabolic pathways, as low as in zeptomole-scale mixtures (Swaminathan et al. 2018), but it remains challenging to accurately identify and allocate all protein molecules involved into their various pathways (Timp \& Timp 2020). However, many studies have developed visual diagrams of complex protein-protein interaction networks, and it is accepted that temperature stress causes quantifiable changes in these metabolic pathways compared to non-stress conditions (Bai et al. 2015; Kostadinova et al. 2011).

Glycolysis is an important metabolic pathway in most organisms, including fungi. Many fungi produce enzymes to break down complex polysaccharides such as cellulose, hemicellulose, pectin and starch to produce glucose (Krishnan et al. 2016; Xiong et al. 2017). Many studies have confirmed that fungi produced a range of extracellular hydrolases to help them utilise different carbon and nitrogen sources under exposure to temperature stress (Krishnan et al. 2017; Tajuddin et al. 2018). The production of these enzymes responds to changing environmental temperature, in order to maintain metabolic requirements and protein turnover. As noted earlier, trehalose production is also important for fungi under temperature stress. Trehalose is known to be important in the acquisition of thermotolerance and desiccation tolerance in many fungal species (and much more widely across multiple groups of biota) (Everatt et al. 2015; Gancedo \& Flores 2004; Liu et al. 2019; Tereshina 2005). In Saccharomyces cerevisiae, trehalose and intracellular water stabilise the membrane structure and other intracellular networks under temperature stress conditions (Piper 1993). Various studies document increased activity of 
400 trehalases, such as the trehalose synthase and fructose-1,6-biphosphatase, in response to heat 401 stress (Bonini et al. 1995; Cai et al. 2009). In addition, enzymes such as cAMP-dependent 402 protein kinase and plasma membrane ATPase also play significant roles in fungal 403 thermotolerance determination (Jurick Ii et al. 2004; Piper 1993). Enolase, an enzyme that 404 converts 2-phosphoglyceric acid to phosphoenolpyruvic acid in glycolysis, is also crucial in the 405 heat stress response of many fungal species and yeasts ( $\mathrm{Ji}$ et al. 2016). It has been suggested that enolase (ENO1) is closely involved in heat stress responses, and ENO1 of yeasts and streptococcal strains isolated from rats has high thermal stability (Cuéllar-Cruz et al. 2013; Iida \& Yahara 1985; Kustrzeba-Wójcicka \& Golczak 2000).

\section{Effect of temperature stress on heat shock proteins (HSPs)}

415

416

417

418

419

420

421

422

423

424

425

426

427

428

429

430

431

432

433

434

435

436

437

438

439

In the event of heat stress, HSPs are produced in cells to protect proteins from aggregation, unfold or refold aggregated proteins, or target them for the degradation pathway. Although initially named following discovery in heat stress experiments, HSPs are a part of general stress responses, produced when cells and organisms are exposed to multiple types of stressors. Most HSPs are molecular chaperones produced constitutively or induced upon cell stress, which can be triggered by a temperature change of just a few degrees (Richter et al. 2010). Heat shock proteins are primarily categorised and named according to their molecular mass, which varies from 10 to $100 \mathrm{kDa}$. Their multifunctional properties have made them an important and reliable target biomarker in various fields such as crop management, plant and microbe adaptation towards environmental stress, and cancer related studies (Jee 2016). HSPs are known to play a role in temperature-stressed environments (Tiwari et al. 2015), but understanding the complexity of the HSP network as a defence mechanism in the cellular environment requires much further research. The cellular functions of the various HSPs that are involved as part of the heat shock response network in fungi, using $S$. cerevisiae as a model, has been discussed in depth (Verghese et al. 2012). Evidence suggests that HSPs are involved in cell cycle arrest (Vergés et al. 2007), metabolic reprogramming (Elliott et al. 1996), modulating cell wall and membrane dynamics (Shaner et al. 2008; Truman et al. 2007; Winkler et al. 2002) and protein aggregation (Nathan et al. 1997).

Heat shock protein 60 (HSP60) is a highly conserved molecule in many organisms and has been found to respond to various stress conditions in fungi. This HSP is upregulated in response to increased temperature in species such as A. fumigatus, Aspergillus terreus, P. chrysogenum, Scedosporium apiospermum, Trichophyton mentagrophytes, Candida albicans and S. cerevisiae (Raggam et al. 2011). HSP60 has also been proposed to play a role in the assembly of precursor polypeptides into oligomeric complexes following incorporation into the mitochondrial matrix (Patriarca \& Maresca 1990). Galello et al. (2014) recently described the interaction of HSP60 and Ira2 with Bcy1, a regulatory subunit of protein kinase A (PKA) in S. cerevisiae. Using an MS-based proteomic approach, this study demonstrated that HSP60 localized the entire PKA- 
440 Ras complex to mitochondria under the regulation of the cAMP-PKA-signalling pathway. There

441

442

443

444

445

446

447

448

449

450

451

452

453

454

455

456

457

458

459

460

461

462

463

464

465

466

467

468

469

470

471

472

473

474

475

476

477

478

479 are also reports of HSP70 having a role in enhancing fungal resistance to heat stress and other abiotic stresses (2010; Montero-Barrientos et al. 2008). The overexpression of HSP0 genes in Trichoderma harzianum T34 resulted in an increase in biomass and enhanced tolerance to other abiotic stresses after heat shock treatment (Montero-Barrientos et al. 2008). Subsequently, the function of the HSP70 gene from T. harzianum T34 was further studied in the transgenic plant, Arabidopsis thaliana, showing that the transgenic plants exhibited higher tolerance towards heat stress (Montero-Barrientos et al. 2010). HSP90, one of the most ubiquitous chaperones in yeasts (Nathan et al. 1997), was found to interact with calcineurin (Imai \& Yahara 2000) and respond to heat stress indirectly through facilitating the activation of the MAPK complex (Truman et al. 2007). More recent work has shown that HSP90 plays a central role in heat stress responses in Fusarium graminearum, in addition to its crucial roles in fungal vegetative growth, reproduction and virulence (Bui et al. 2016). In A. fumigatus, HSP90 has been implicated in drug resistance, as disruption of the HSP90 circuitry leads to activation of antifungal activity in caspofungin (Lamoth et al. 2016).

\section{Concluding remarks}

The importance of fungi and of mycological studies in the development of the bioeconomy and in environmental monitoring has been accepted and highlighted by researchers worldwide. Excellent reviews are available documenting fungal response towards abiotic stress and how fungi can affect the tolerance of other organisms, especially plants, towards multiple stressors (A'Bear et al. 2014a; Coleman-Derr \& Tringe 2014; East 2013; McCotter et al. 2016; Rangel et al. 2018). Many studies have set out to understand fungal heat stress response mechanisms in order to help develop tools for crop monitoring and production as well as producing heattolerance species that are better able to response to climate change challenges (Jagadish et al. 2010; Simova-Stoilova et al. 2016). Research on fungal molecular responses towards temperature stress has been widely explored using different omics approaches. Studies on fungal genomes, transcriptomes, secretomes and proteomes have provided new knowledge and understanding of these responses (Albrecht et al. 2010; Bai et al. 2015; Cologna et al. 2018; Kroll et al. 2014). The outcomes of these studies will need to be fully exploited to maximise the potential of fungi both in biotechnological industries and in natural environment under current climate change scenarios (Classen et al. 2015; Lange et al. 2012; Rangel et al. 2018).

As is clear from this review, there is currently limited available literature documenting the use of proteomics in studying the effects of temperature stress on fungal proteins, and most reports to date have focused on pathogenic fungi. Despite the tremendous promise of proteomics, technical limitations that affect sensitivity and resolution continue to limit its practical utility. In almost all studies considered here, detection was limited to medium and high abundance proteins, the majority of which were related to metabolism and chaperones. With currently available data from proteomics, it remains difficult to provide comprehensive descriptions of the biological 
480

481

482

483

484

485

486

487

488

489

490

491

492

493

494

495

496

497

498

499

500

501

502

503

504

505

506

507

508

509

510

511

512

513

514

515

516

517

518

changes that can be observed. At present this means our ability to identify specific biomarkers for any given change is very limited, as many confounding factors can influence the production of these more abundant proteins.

These issues can be overcome in future. More thorough interrogation of the proteome, including integration within multi-omics platforms, will allow for deeper insights into the mechanisms underlying changing cell physiology. If potential biomarkers are to be identified, proteomic analyses must go beyond medium and high abundance proteins. Several strategies can be employed to achieve this. Specific sub-proteomes of proteins and their associated pathways already identified as changing in initial analyses can be further explored. A targeted proteomics approach, for example looking at specific sub-fractions of the cell (cell wall, specific organelles, etc.) may be beneficial. This will allow for the identification of low abundance proteins that may include, for instance, signaling proteins with specific roles in heat stress response. Further information can also be obtained by conducting investigations using multi-omics platforms applied to the same samples simultaneously, to provide both complementary and confirmatory information.

\section{Acknowledgements}

The authors acknowledge the Malaysian Ministry of Higher Education (MOHE) through their funding programme Higher Centre of Excellence (HiCoE) (grant number IOES-2014G), and Universiti Malaya Research Programme (UMRP) (grant number RP026A-18SUS), and postgraduate sponsorship from the Majlis Amanah Rakyat Malaysia (MARA Scholarship Programme). We also thank Prof. Peter Convey from the British Antarctic Survey (BAS), United Kingdom, for commenting on the manuscript.

\section{References}

A'Bear AD, Jones TH, and Boddy L. 2014a. Potential impacts of climate change on interactions among saprotrophic cord-forming fungal mycelia and grazing soil invertebrates. Fungal Ecology 10:3443. 10.1016/j.funeco.2013.01.009:

A'Bear AD, Jones TH, and Boddy L. 2014b. Size matters: What have we learnt from microcosm studies of decomposer fungus-invertebrate interactions? Soil Biology and Biochemistry 78:274-283. 10.1016/j.soilbio.2014.08.009:

Al-Bader N, Vanier G, Liu H, Gravelat FN, Urb M, Hoareau CM, Campoli P, Chabot J, Filler SG, and Sheppard DC. 2010. Role of trehalose biosynthesis in Aspergillus fumigatus development, stress response, and virulence. Infection and Immunity 78:3007-3018. 10.1128/IAI.00813-09:

Albrecht D, Guthke R, Brakhage AA, and Kniemeyer O. 2010. Integrative analysis of the heat shock response in Aspergillus fumigatus. BMC Genomics 11:32. 10.1186/1471-2164-11-32: 
519

520

521

522

523

524

525

526

527

528

529

530

531

532

533

534

535

536

537

538

539

540

541

542

543

544

545

546

547

548

549

550

551

552

553

554

555

556

557

558

559

560

561

562

563

Aragno M. 1981. Responses of Microorganisms to Temperature. In: Lange OL, Nobel PS, Osmond CB, and Ziegler H, eds. Physiological Plant Ecology I: Responses to the Physical Environment. Berlin, Heidelberg: Springer Berlin Heidelberg, 339-369.

Bagwell SN, and Ricker JV. 2019. Antifreeze proteins: effective adaptations of organisms for low temperature survival. BIOS 90:158-170, 113. 10.1893/BIOS-D-17-00007:

Bai Y, Wang S, Zhong H, Yang Q, Zhang F, Zhuang Z, Yuan J, Nie X, and Wang S. 2015. Integrative analyses reveal transcriptome-proteome correlation in biological pathways and secondary metabolism clusters in A. flavus in response to temperature. Scientific Reports 5:14582. 10.1038/srep14582:

Barros BH, da Silva SH, dos ReisMarques Edos R, Rosa JC, Yatsuda AP, Roberts DW, and Braga GU. 2010. A proteomic approach to identifying proteins differentially expressed in conidia and mycelium of the entomopathogenic fungus Metarhizium acridum. Fungal Biology 114:572-579. 10.1016/j.funbio.2010.04.007:

Bianco L, and Perrotta G. 2015. Methodologies and perspectives of proteomics applied to filamentous fungi: from sample preparation to secretome analysis. International Journal of Molecular Sciences 16:5803-5829. 10.3390/ijms16035803:

Bonini BM, Neves MJ, Jorge JA, and Terenzi HF. 1995. Effects of temperature shifts on the metabolism of trehalose in Neurospora crassa wild type and a trehalase-deficient (tre) mutant. Evidence against the participation of periplasmic trehalase in the catabolism of intracellular trehalose. Biochimica et Biophysica Acta (BBA) - General Subjects 1245:339-347. 10.1016/03044165(95)00098-4:

Bui D-C, Lee Y, Lim JY, Fu M, Kim J-C, Choi GJ, Son H, and Lee Y-W. 2016. Heat shock protein 90 is required for sexual and asexual development, virulence, and heat shock response in Fusarium graminearum. Scientific Reports 6:28154. 10.1038/srep28154:

Cai Z, Peng G, Cao Y, Liu Y, Jin K, and Xia Y. 2009. Trehalose-6-phosphate synthase 1 from Metarhizium anisopliae: clone, expression and properties of the recombinant. Journal of Bioscience and Bioengineering 107:499-505. 10.1016/j.jbiosc.2009.01.007:

Cavicchioli R, Thomas T, and Curmi PM. 2000. Cold stress response in Archaea. Extremophiles 4:321331.

Chandler JM, Treece ER, Trenary HR, Brenneman JL, Flickner TJ, Frommelt JL, Oo ZM, Patterson MM, Rundle WT, Valle OV, Kim TD, Walker GR, and Cooper CR, Jr. 2008. Protein profiling of the dimorphic, pathogenic fungus, Penicillium marneffei. Proteome Science 6:17. 10.1186/14775956-6-17:

Clarke A. 2018. Principles of thermal ecology : temperature, energy and life: Oxford : Oxford University Press.

Classen AT, Sundqvist MK, Henning JA, Newman GS, Moore JAM, Cregger MA, Moorhead LC, and Patterson CM. 2015. Direct and indirect effects of climate change on soil microbial and soil microbial-plant interactions: What lies ahead? Ecosphere 6:1-21. 10.1890/ES15-00217.1:

Coleman-Derr D, and Tringe SG. 2014. Building the crops of tomorrow: advantages of symbiont-based approaches to improving abiotic stress tolerance. Frontiers in Microbiology 5:283. 10.3389/fmicb.2014.00283:

Cologna NdMd, Gómez-Mendoza DP, Zanoelo FF, Giannesi GC, Guimarães NCdA, Moreira LRdS, Filho EXF, and Ricart CAO. 2018. Exploring Trichoderma and Aspergillus secretomes: Proteomics approaches for the identification of enzymes of biotechnological interest. Enzyme and Microbial Technology 109:1-10. 10.1016/j.enzmictec.2017.08.007: 
564

565

566

567

568

569

570

571

572

573

574

575

576

577

578

579

580

581

582

583

584

585

586

587

588

589

590

591

592

593

594

595

596

597

598

599

600

601

602

603

604

605

606

Cuéllar-Cruz M, Gutiérrez-Sánchez G, López-Romero E, Ruiz-Baca E, Villagómez-Castro JC, and Rodríguez-Sifuentes L. 2013. Identification of Candida albicans heat shock proteins and Candida glabrata and Candida krusei enolases involved in the response to oxidative stress. Central European Journal of Biology 8:337-345. 10.2478/s11535-013-0138-9:

Daim LD, Ooi TE, Yusof HM, Majid NA, and Karsani SA. 2015. Optimization of Protein Extraction and Two-Dimensional Electrophoresis Protocols for Oil Palm Leaf. The Protein Journal 34:304-312. 10.1007/s10930-015-9626-x:

Delgado J, Owens RA, Doyle S, Asensio MA, and Nunez F. 2015. Impact of the antifungal protein PgAFP from Penicillium chrysogenum on the protein profile in Aspergillus flavus. Applied Microbiology and Biotechnology 99:8701-8715. 10.1007/s00253-015-6731-x:

Dix NJ, and Webster J. 1995. Fungi of Extreme Environments. In: Dix NJ, and Webster J, eds. Fungal Ecology. Dordrecht: Springer Netherlands, 322-340.

East R. 2013. Microbiome: Soil science comes to life. Nature 501:S18. 10.1038/501S18a:

Elliott B, Haltiwanger RS, and Futcher B. 1996. Synergy between trehalose and Hsp104 for thermotolerance in Saccharomyces cerevisiae. Genetics 144:923-933.

Ene IV, Brunke S, Brown AJP, and Hube B. 2014. Metabolism in fungal pathogenesis. Cold Spring Harbor perspectives in medicine 4:a019695-a019695. 10.1101/cshperspect.a019695:

Everatt MJ, Convey P, Bale JS, Worland MR, and Hayward SA. 2015. Responses of invertebrates to temperature and water stress: A polar perspective. Journal of Thermal Biology 54:118-132. 10.1016/j.jtherbio.2014.05.004:

Fan M, Shen J, Yuan L, Jiang R, Chen X, Davies WJ, and Zhang F. 2012. Improving crop productivity and resource use efficiency to ensure food security and environmental quality in China. Journal of Experimental Botany 63:13-24. 10.1093/jxb/err248:

Fenice M. 2016. The Psychrotolerant Antarctic Fungus Lecanicillium muscarium CCFEE 5003: A Powerful Producer of Cold-Tolerant Chitinolytic Enzymes. Molecules 21. 10.3390/molecules21040447:

Francis J, and Skific N. 2015. Evidence linking rapid Arctic warming to mid-latitude weather patterns. Philosophical Transactions of the Royal Society A 373:20140170.

Fricker L. 2018. Quantitative Peptidomics: General Considerations. In: Schrader M, and Fricker L, eds. Peptidomics: Methods and Strategies. New York, NY: Springer New York, 121-140.

Galello F, Moreno S, and Rossi S. 2014. Interacting proteins of protein kinase A regulatory subunit in Saccharomyces cerevisiae. Journal of Proteomics 109:261-275. 10.1016/j.jprot.2014.07.008:

Gancedo C, and Flores C-L. 2004. The importance of a functional trehalose biosynthetic pathway for the life of yeasts and fungi. FEMS Yeast Research 4:351-359. 10.1016/S1567-1356(03)00222-8:

Gauthier GM. 2017. Fungal Dimorphism and Virulence: Molecular Mechanisms for Temperature Adaptation, Immune Evasion, and In Vivo Survival. Mediators of Inflammation 2017:8491383. 10.1155/2017/8491383:

Hu B, Luo M, Ji X, Lin L, Wei Y, and Zhang Q. 2016. Proteomic analysis of Mortierella isabellina M622 during cold stress. Archives of Microbiology 198:869-876. 10.1007/s00203-016-1238-0:

Iida H, and Yahara I. 1985. Yeast heat-shock protein of Mr 48,000 is an isoprotein of enolase. Nature 315:688-690. 10.1038/315688a0:

Imai J, and Yahara I. 2000. Role of HSP90 in salt stress tolerance via stabilization and regulation of calcineurin. Molecular and Cellular Biology 20:9262-9270.

Peer] reviewing PDF | (2020:02:46059:2:0:NEW 19 Oct 2020) 
607

608

609

610

611

612

613

614

615

616

617

618

619

620

621

622

623

624

625

626

627

628

629

630

631

632

633

634

635

636

637

638

639

640

641

642

643

644

645

646

647

648

649

IPCC. 2018. Summary for Policymakers. In: Global Warming of $15^{\circ} \mathrm{C}$ An IPCC Special Report on the impacts of global warming of $15^{\circ} \mathrm{C}$ above pre-industrial levels and related global greenhouse gas emission pathways, in the context of strengthening the global response to the threat of climate change, sustainable development, and efforts to eradicate poverty. Masson-Delmotte V, P. Zhai, H.-O. Pörtner, D. Roberts, J. Skea, P.R. Shukla, A. Pirani, W. Moufouma-Okia, C. Péan, R. Pidcock, S. Connors, J.B.R. Matthews, Y. Chen, X. Zhou, M.I. Gomis, E. Lonnoy, T. Maycock, M. Tignor, and T. Waterfield editor.: World Meteorological Organization. Geneva, Switzerland.

Isola D, Marzban G, Selbmann L, Onofri S, Laimer M, and Sterflinger K. 2011. Sample preparation and 2-DE procedure for protein expression profiling of black microcolonial fungi. Fungal Biology 115:971-977. 10.1016/j.funbio.2011.03.001:

Jagadish SVK, Muthurajan R, Oane R, Wheeler TR, Heuer S, Bennett J, and Craufurd PQ. 2010. Physiological and proteomic approaches to address heat tolerance during anthesis in rice (Oryza sativa L.). Journal of Experimental Botany 61:143-156. 10.1093/jxb/erp289:

Jee H. 2016. Size dependent classification of heat shock proteins: a mini-review. Journal of exercise rehabilitation 12:255-259. 10.12965/jer.1632642.321:

Ji H, Wang J, Guo J, Li Y, Lian S, Guo W, Yang H, Kong F, Zhen L, Guo L, and Liu Y. 2016. Progress in the biological function of alpha-enolase. Animal Nutrition 2:12-17. 10.1016/j.aninu.2016.02.005:

Jurick Ii WM, Dickman MB, and Rollins JA. 2004. Characterization and functional analysis of a cAMPdependent protein kinase A catalytic subunit gene (pka1) in Sclerotinia sclerotiorum. Physiological and Molecular Plant Pathology 64:155-163. 10.1016/j.pmpp.2004.07.004:

Karpievitch YV, Polpitiya AD, Anderson GA, Smith RD, and Dabney AR. 2010. Liquid Chromatography Mass Spectrometry-Based Proteomics: Biological and Technological Aspects. Annals of Applied Statistics 4:1797-1823. 10.1214/10-AOAS341:

Keller NP. 2019. Fungal secondary metabolism: regulation, function and drug discovery. Nature reviews Microbiology 17:167-180. 10.1038/s41579-018-0121-1:

Kostadinova N, Vassilev S, Spasova B, and Angelova M. 2011. Cold stress in Antarctic fungi targets enzymes of the glycolytic pathway and tricarboxylic acid cycle. Biotechnology and Biotechnological Equipment 25:50-57. 10.5504/BBEQ.2011.0122:

Krishnan A, Convey P, Gonzalez-Rocha G, and Alias SA. 2016. Production of extracellular hydrolase enzymes by fungi from King George Island. Polar Biology 39:65-76. 10.1007/s00300-014-1606$7:$

Krishnan A, Convey P, Gonzalez M, Smykla J, and Alias SA. 2017. Effects of temperature on extracellular hydrolase enzymes from soil microfungi. Polar Biology. 10.1007/s00300-017-2215$\mathrm{z:}$

Kroll K, Pahtz V, and Kniemeyer O. 2014. Elucidating the fungal stress response by proteomics. $J$ Proteomics 97:151-163. 10.1016/j.jprot.2013.06.001:

Kundzewicz ZW, Ulbrich U, brücher T, Graczyk D, Krüger A, Leckebusch GC, Menzel L, Pińskwar I, Radziejewski M, and Szwed M. 2005. Summer Floods in Central Europe - Climate Change Track? Natural Hazards 36:165-189. 10.1007/s1 1069-004-4547-6:

Kustrzeba-Wójcicka I, and Golczak M. 2000. Enolase from Candida albicans — purification and characterization. Comparative Biochemistry and Physiology Part B: Biochemistry and Molecular Biology 126:109-120. 10.1016/S0305-0491(00)00169-3:

Peer) reviewing PDF | (2020:02:46059:2:0:NEW 19 Oct 2020) 
650

651

652

653

654

655

656

657

658

659

660

661

662

663

664

665

666

667

668

669

670

671

672

673

674

675

676

677

678

679

680

681

682

683

684

685

686

687

688

689

690

691

692

693

Kyaschenko J, Clemmensen KE, Hagenbo A, Karltun E, and Lindahl BD. 2017. Shift in fungal communities and associated enzyme activities along an age gradient of managed Pinus sylvestris stands. The Isme Journal 11:863. 10.1038/ismej.2016.184:

Lamoth F, Juvvadi PR, and Steinbach WJ. 2016. Heat shock protein 90 (Hsp90): A novel antifungal target against Aspergillus fumigatus. Critical Reviews in Microbiology 42:310-321. 10.3109/1040841X.2014.947239:

Lange L, Bech L, Busk PK, Grell MN, Huang Y, Lange M, Linde T, Pilgaard B, Roth D, and Tong X. 2012. The importance of fungi and of mycology for a global development of the bioeconomy. IMA Fungus 3:87-92. 10.5598/imafungus.2012.03.01.09:

Lau SK, Tse H Fau - Chan JSY, Chan Js Fau - Zhou AC, Zhou Ac Fau - Curreem SOT, Curreem So Fau Lau CCY, Lau Cc Fau - Yuen K-Y, Yuen Ky Fau - Woo PCY, and Woo PC. 2013. Proteome profiling of the dimorphic fungus Penicillium marneffei extracellular proteins and identification of glyceraldehyde-3-phosphate dehydrogenase as an important adhesion factor for conidial attachment. The FEBS Journal 280:1742-4658. 10.1111/febs.12566:

Lesk C, Rowhani P, and Ramankutty N. 2016. Influence of extreme weather disasters on global crop production. Nature 529:84. 10.1038/nature16467:

Liu J-Y, Men J-1, Chang M-c, Feng C-p, and Yuan L-G. 2017. iTRAQ-based quantitative proteome revealed metabolic changes of Flammulina velutipes mycelia in response to cold stress. Journal of Proteomics 156:75-84. 10.1016/j.jprot.2017.01.009:

Liu X-m, Wu X-1, Gao W, Qu J-b, Chen Q, Huang C-y, and Zhang J-x. 2019. Protective roles of trehalose in Pleurotus pulmonarius during heat stress response. Journal of Integrative Agriculture 18:428437. 10.1016/S2095-3119(18)62010-6:

McCotter SW, Horianopoulos LC, and Kronstad JW. 2016. Regulation of the fungal secretome. Current genetics 62:533-545. 10.1007/s00294-016-0578-2:

McNeil JC, and Palazzi DL. 2012. Ustilago as a Cause of Fungal Peritonitis: Case Report and Review of the Literature. Journal of the Pediatric Infectious Diseases Society 1:337-339. 10.1093/jpids/pis043:

Miteva-Staleva JG, Krumova ET, Vassilev SV, and Angelova MB. 2017. Cold-stress response during the stationary-growth phase of Antarctic and temperate-climate Penicillium strains. Microbiology 163:1042-1051. 10.1099/mic.0.000486:

Montero-Barrientos M, Hermosa R, Cardoza RE, Gutiérrez S, Nicolás C, and Monte E. 2010. Transgenic expression of the Trichoderma harzianum hsp70 gene increases Arabidopsis resistance to heat and other abiotic stresses. Journal of Plant Physiology 167:659-665. 10.1016/j.jplph.2009.11.012:

Montero-Barrientos M, Hermosa R, Nicolás C, Cardoza RE, Gutiérrez S, and Monte E. 2008. Overexpression of a Trichoderma HSP70 gene increases fungal resistance to heat and other abiotic stresses. Fungal Genetics and Biology 45:1506-1513. 10.1016/j.fgb.2008.09.003:

Mühlhofer M, Berchtold E, Stratil CG, Csaba G, Kunold E, Bach NC, Sieber SA, Haslbeck M, Zimmer R, and Buchner J. 2019. The Heat Shock Response in Yeast Maintains Protein Homeostasis by Chaperoning and Replenishing Proteins. Cell Reports 29:4593-4607.e4598. 10.1016/j.celrep.2019.11.109:

Nathan DF, Vos MH, and Lindquist S. 1997. In vivo functions of the Saccharomyces cerevisiae Hsp90 chaperone. Proceedings of the National Academy of Sciences 94:12949. 10.1073/pnas.94.24.12949:

PeerJ reviewing PDF | (2020:02:46059:2:0:NEW 19 Oct 2020) 
694

695

696

697

698

699

700

701

702

703

704

705

706

707

708

709

710

711

712

713

714

715

716

717

718

719

720

721

722

723

724

725

726

727

728

729

730

731

732

733

734

735

736

737

Nwaka S, and Holzer H. 1997. Molecular Biology of Trehalose and the Trehalases in the Yeast Saccharomyces cerevisiae. In: Moldave K, ed. Progress in Nucleic Acid Research and Molecular Biology: Academic Press, 197-237.

O’ Neill JS, Hoyle NP, Robertson JB, Edgar RS, Beale AD, Peak-Chew SY, Day J, Costa ASH, Frezza C, and Causton HC. 2020. Eukaryotic cell biology is temporally coordinated to support the energetic demands of protein homeostasis. Nature Communications 11:4706. 10.1038/s41467-020-18330$\mathrm{x}$ :

Overland J, Francis JA, Hall R, Hanna E, Kim S-J, and Vihma T. 2015. The melting Arctic and midlatitude weather patterns: are they connected? Journal of Climate 28:7917-7932. 10.1175/JCLI-D-14-00822.1:

Patriarca EJ, and Maresca B. 1990. Acquired thermotolerance following heat shock protein synthesis prevents impairment of mitochondrial ATPase activity at elevated temperatures in Saccharomyces cerevisiae. Experimental Cell Research 190:57-64. 10.1016/00144827(90)90143-X:

Perez-Nadales E, Almeida Nogueira MF, Baldin C, Castanheira S, El Ghalid M, Grund E, Lengeler K, Marchegiani E, Mehrotra PV, Moretti M, Naik V, Oses-Ruiz M, Oskarsson T, Schäfer K, Wasserstrom L, Brakhage AA, Gow NAR, Kahmann R, Lebrun M-H, Perez-Martin J, Di Pietro A, Talbot NJ, Toquin V, Walther A, and Wendland J. 2014. Fungal model systems and the elucidation of pathogenicity determinants. Fungal Genetics and Biology 70:42-67. 10.1016/j.fgb.2014.06.011:

Piper PW. 1993. Molecular events associated with acquisition of heat tolerance by the yeast Saccharomyces cerevisiae. FEMS Microbiology Reviews 11:339-355.

Raggam RB, Salzer HJ, Marth E, Heiling B, Paulitsch AH, and Buzina W. 2011. Molecular detection and characterisation of fungal heat shock protein 60. Mycoses 54:e394-399. 10.1111/j.14390507.2010.01933.x:

Rangel DEN, Finlay RD, Hallsworth JE, Dadachova E, and Gadd GM. 2018. Fungal strategies for dealing with environment- and agriculture-induced stresses. Fungal Biology. 10.1016/j.funbio.2018.02.002:

Rao IM, Beebe SE, Polania J, Grajales M, Cajiao C, Ricaurte J, GarcÍA R, and Rivera M. 2016 a. Evidence for genotypic differences among elite lines of common bean in the ability to remobilize photosynthate to increase yield under drought. The Journal of Agricultural Science 155:857-875. 10.1017/S0021859616000915:

Rao IM, Miles JW, Beebe SE, and Horst WJ. 2016b. Root adaptations to soils with low fertility and aluminium toxicity. Annals of Botany 118:593-605. 10.1093/aob/mcw073:

Reed CJ, Lewis H, Trejo E, Winston V, and Evilia C. 2013. Protein adaptations in archaeal extremophiles. Archaea 2013:373275. 10.1155/2013/373275:

Richter K, Haslbeck M, and Buchner J. 2010. The Heat Shock Response: Life on the Verge of Death. Molecular Cell 40:253-266. 10.1016/j.molcel.2010.10.006:

Salmeron-Santiago KG, Pardo JP, Flores-Herrera O, Mendoza-Hernandez G, Miranda-Arango M, and Guerra-Sanchez G. 2011. Response to osmotic stress and temperature of the fungus Ustilago maydis. Archives in Microbiology 193:701-709. 10.1007/s00203-011-0706-9:

Sarmiento F, Peralta R, and Blamey JM. 2015. Cold and Hot Extremozymes: Industrial Relevance and Current Trends. Frontiers in Bioengineering and Biotechnology 3:148.

10.3389/fbioe.2015.00148:

Peer) reviewing PDF | (2020:02:46059:2:0:NEW 19 Oct 2020) 
738

739

740

741

742

743

744

745

746

747

748

749

750

751

752

753

754

755

756

757

758

759

760

761

762

763

764

765

766

767

768

769

770

771

772

773

774

775

776

777

778

779

780

781

Schulte PM. 2015. The effects of temperature on aerobic metabolism: towards a mechanistic understanding of the responses of ectotherms to a changing environment. The Journal of Experimental Biology 218:1856. 10.1242/jeb.118851:

Shaner L, Gibney PA, and Morano KA. 2008. The Hsp110 protein chaperone Sse1 is required for yeast cell wall integrity and morphogenesis. Current genetics 54:1-11. 10.1007/s00294-008-0193-y:

Simova-Stoilova L, Vassileva V, and Feller U. 2016. Selection and Breeding of Suitable Crop Genotypes for Drought and Heat Periods in a Changing Climate: Which Morphological and Physiological Properties Should Be Considered? Agriculture-Basel 6:19. 10.3390/agriculture6020026:

Su Y, Jiang X, Wu W, Wang M, Hamid MI, Xiang M, and Liu X. 2016. Genomic, Transcriptomic, and Proteomic Analysis Provide Insights Into the Cold Adaptation Mechanism of the Obligate Psychrophilic Fungus Mrakia psychrophila. G3: Genes|Genomes|Genetics 6:3603-3613. 10.1534/g3.116.033308:

Suarez RK, and Moyes CD. 2012. Metabolism in the age of 'omes'. The Journal of Experimental Biology 215:2351. 10.1242/jeb.059725:

Swaminathan J, Boulgakov AA, Hernandez ET, Bardo AM, Bachman JL, Marotta J, Johnson AM, Anslyn EV, and Marcotte EM. 2018. Highly parallel single-molecule identification of proteins in zeptomole-scale mixtures. Nature Biotechnology 36:1076-1082. 10.1038/nbt.4278:

Tajuddin N, Rizman-Idid M, Convey P, and Alias Siti A. 2018. Thermal adaptation in a marine-derived tropical strain of Fusarium equiseti and polar strains of Pseudogymnoascus spp. under different nutrient sources. In: Botanica Marina. p 9.

Teo LH, and Tay YK. 2006. Ustilago species infection in humans. British Journal of Dermatology 155:1096-1097. 10.1111/j.1365-2133.2006.07515.x:

Tereshina VM. 2005. Thermotolerance in Fungi: The Role of Heat Shock Proteins and Trehalose. Microbiology 74:247-257. 10.1007/s11021-005-0059-y:

Tesei D, Marzban G, Marchetti-Deschmann M, Tafer H, Arcalis E, and Sterflinger K. 2015. Proteome of tolerance fine-tuning in the human pathogen black yeast Exophiala dermatitidis. Journal of Proteomics 128:39-57. 10.1016/j.jprot.2015.07.007:

Tesei D, Marzban G, Zakharova K, Isola D, Selbmann L, and Sterflinger K. 2012. Alteration of protein patterns in black rock inhabiting fungi as a response to different temperatures. Fungal Biology 116:932-940. 10.1016/j.funbio.2012.06.004:

Timp W, and Timp G. 2020. Beyond mass spectrometry, the next step in proteomics. Science Advances 6:eaax8978. 10.1126/sciadv.aax8978:

Tiwari S, Thakur R, and Shankar J. 2015. Role of Heat-Shock Proteins in Cellular Function and in the Biology of Fungi. Biotechnology Research International 2015.

Truman AW, Millson SH, Nuttall JM, Mollapour M, Prodromou C, and Piper PW. 2007. In the Yeast Heat Shock Response, Hsf1-Directed Induction of Hsp90 Facilitates the Activation of the Slt2 (Mpk1) Mitogen-Activated Protein Kinase Required for Cell Integrity. Eukaryotic Cell 6:744. 10.1128/EC.00009-07:

Vergés E, Colomina N, Garí E, Gallego C, and Aldea M. 2007. Cyclin Cln3 Is Retained at the ER and Released by the J Chaperone Ydj1 in Late G1 to Trigger Cell Cycle Entry. Molecular Cell 26:649-662. 10.1016/j.molcel.2007.04.023:

Verghese J, Abrams J, Wang Y, and Morano KA. 2012. Biology of the Heat Shock Response and Protein Chaperones: Budding Yeast as a Model System. Microbiology and Molecular Biology Reviews 76:115. 10.1128/MMBR.05018-11:

PeerJ reviewing PDF | (2020:02:46059:2:0:NEW 19 Oct 2020) 
782

783

784

785

786

787

788

789

790

791

792

793

794

795

796

797

798

799

800

801

802

803

Williams TJ, Lauro FM, Ertan H, Burg DW, Poljak A, Raftery MJ, and Cavicchioli R. 2011. Defining the response of a microorganism to temperatures that span its complete growth temperature range (-2 degrees $\mathrm{C}$ to 28 degrees C) using multiplex quantitative proteomics. Environmental Microbiology 13:2186-2203. 10.1111/j.1462-2920.2011.02467.x:

Winkler A, Arkind C, Mattison CP, Burkholder A, Knoche K, and Ota I. 2002. Heat Stress Activates the Yeast High-Osmolarity Glycerol Mitogen-Activated Protein Kinase Pathway, and Protein Tyrosine Phosphatases Are Essential under Heat Stress. Eukaryotic Cell 1:163. 10.1128/EC.1.2.163-173.2002:

Xiong Y, Wu VW, Lubbe A, Qin L, Deng S, Kennedy M, Bauer D, Singan VR, Barry K, Northen TR, Grigoriev IV, and Glass NL. 2017. A fungal transcription factor essential for starch degradation affects integration of carbon and nitrogen metabolism. PLoS genetics 13:e1006737-e1006737. 10.1371/journal.pgen.1006737:

Yan Z, Zhao M, Wu X, and Zhang J. 2020. Metabolic Response of Pleurotus ostreatus to Continuous Heat Stress. Frontiers in Microbiology 10:3148-3148. 10.3389/fmicb.2019.03148:

Zakharova K, Sterflinger K, Razzazi-Fazeli E, Noebauer K, and Marzban G. 2014. Global proteomics of the extremophile black fungus Cryomyces antarcticus using 2D-Electrophoresis. Natural Science 2014.

Zhang F, Chen X, and Vitousek P. 2013. An experiment for the world. Nature 497:33. 10.1038/497033a:

Zhang X, Ren A, Li M-J, Cao P-F, Chen T-X, Zhang G, Shi L, Jiang A-L, and Zhao M-W. 2016. Heat Stress Modulates Mycelium Growth, Heat Shock Protein Expression, Ganoderic Acid Biosynthesis, and Hyphal Branching of Ganoderma lucidum via Cytosolic $\mathrm{Ca}^{2+}$. Applied and Environmental Microbiology 82:4112. 10.1128/AEM.01036-16: 


\section{Table $\mathbf{1}$ (on next page)}

Summary of fungal proteomic profiling analysis when exposed to high temperature stress (work published from 2008-2020).

$T_{\text {exp }}$ - Temperature of exposure, $T_{\text {opt }}$ - Temperature of optimal growth

Proteomic profiling approaches.

(1) - Gel- free methods

(2) - Gel-based method

* - Non-conclusive remarks (no proteins identification involved) 
Table 1: Summary of fungal proteomic profiling analysis when exposed to high temperature stress (work published from 2008-2020)

\begin{tabular}{|c|c|c|c|c|c|c|c|c|}
\hline $\begin{array}{l}\mathbf{T}_{e x p} \\
\left({ }^{\circ} \mathrm{C}\right)\end{array}$ & $\begin{array}{l}\mathbf{T}_{\text {opt }} \\
\left({ }^{\circ} \mathbf{C}\right)\end{array}$ & Time & Species & $\begin{array}{l}\text { \# no. of } \\
\text { proteins }\end{array}$ & & Proteins identified & $\begin{array}{c}\text { Classification/Pathways } \\
\text { involved }\end{array}$ & Refs. \\
\hline $20^{\circ} \mathrm{C}$ & $12^{\circ} \mathrm{C}$ & $\begin{array}{c}1 \\
\text { month }\end{array}$ & $\begin{array}{l}\text { Mrakia } \\
\text { psychrophila }^{(1)}\end{array}$ & 1673 & Down & $\begin{array}{l}\text { Citrate synthase, DLST, } \\
\text { LSC2 } \\
\text { MTCP1 } \\
\text { CLD1 }\end{array}$ & $\begin{array}{l}\text { TCA cycle } \\
\text { Oxidative phosphorylation } \\
\text { Glycerophospholipid } \\
\text { metabolism }\end{array}$ & $\begin{array}{l}\text { (Su et al. } \\
\text { 2016) }\end{array}$ \\
\hline & & & & & Up & $\begin{array}{l}\text { DNAJ } \\
\text { MPSY4181, MPSY2821 }\end{array}$ & $\begin{array}{l}\text { Heat shock proteins } \\
\text { MFS transporters }\end{array}$ & \\
\hline $28^{\circ} \mathrm{C}$ & $15^{\circ} \mathrm{C}$ & 7 days & $\begin{array}{l}\text { Friedmanniomyces } \\
\text { endolithicus }^{(2)}\end{array}$ & 284 & Down & $\begin{array}{l}\text { Reduced no. of protein spots } \\
\text { (141) }\end{array}$ & $\begin{array}{l}\text { * Reduction in total number of } \\
\text { protein spots, indicating a lack } \\
\text { of a heat shock response }\end{array}$ & $\begin{array}{l}\text { (Tesei et al. } \\
\text { 2012) }\end{array}$ \\
\hline $37^{\circ} \mathrm{C}$ & $25^{\circ} \mathrm{C}$ & 1 day & $\begin{array}{l}\text { Penicillium } \\
\text { marneffei }^{(2)}\end{array}$ & 270 & Up & $\begin{array}{l}\text { Hsp 30, Hsp 70, antigenic } \\
\text { mitochondrial protein } \\
\text { HSP60 hypothetical protein } \\
\text { (activator of HSP90 } \\
\text { ATPase) } \\
\text { succinyl-CoA synthetase } \\
\text { alpha subunit, beta subunit } \\
\text { of ATP synthase, NAD- } \\
\text { dependent } \\
\text { formate dehydrogenase } \\
\text { adenylate kinase, } \\
\text { phosphoglycerate kinase } \\
\text { Ran GTPase spil } \\
\text { Cdc48p } \\
\text { UDP-N-acetylglucosamine } \\
\text { pyrophosphorylase }\end{array}$ & $\begin{array}{l}\text { Regulate mitotic activities } \\
\text { Cell cycle and division } \\
\text { Synthesis of } \mathrm{N} \text { - } \\
\text { acetylglucosamine } \\
\text { (monomeric component of } \\
\text { cell-wall chitin) }\end{array}$ & $\begin{array}{l}\text { (Chandler et } \\
\text { al. 2008) }\end{array}$ \\
\hline $37^{\circ} \mathrm{C}$ & $28^{\circ} \mathrm{C}$ & $\begin{array}{c}1.5 \\
\text { days }\end{array}$ & $\begin{array}{l}\text { Aspergillus flavus } \\
\text { (1) }\end{array}$ & 3886 & Down & $\begin{array}{l}\text { 2-heptaprenyl-1,4- } \\
\text { naphthoquinone } \\
\text { methyltransferase, }\end{array}$ & $\begin{array}{l}\text { Translation and biosynthetic } \\
\text { pathways }\end{array}$ & $\begin{array}{c}\text { (Bai et al. } \\
\text { 2015) }\end{array}$ \\
\hline
\end{tabular}




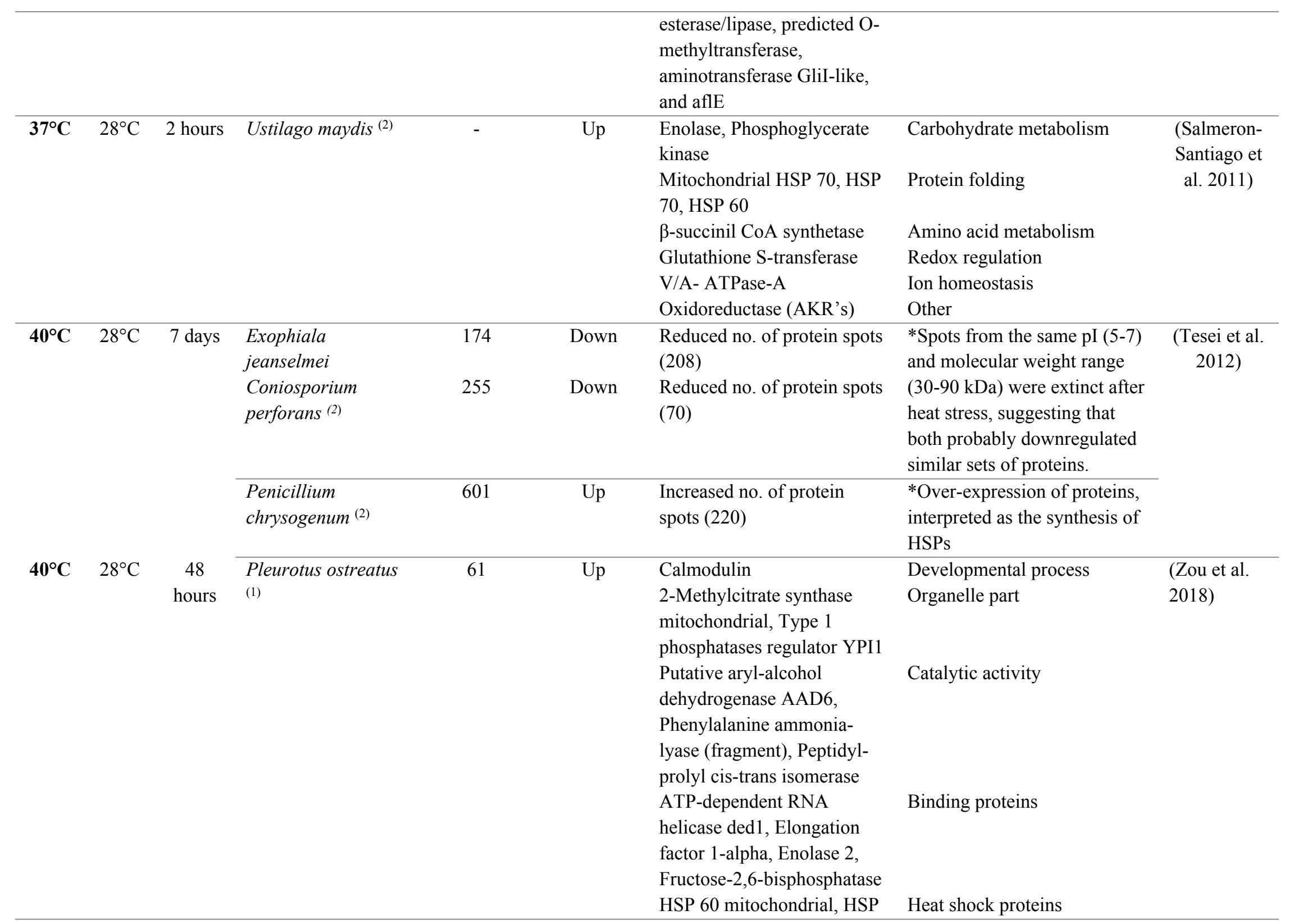




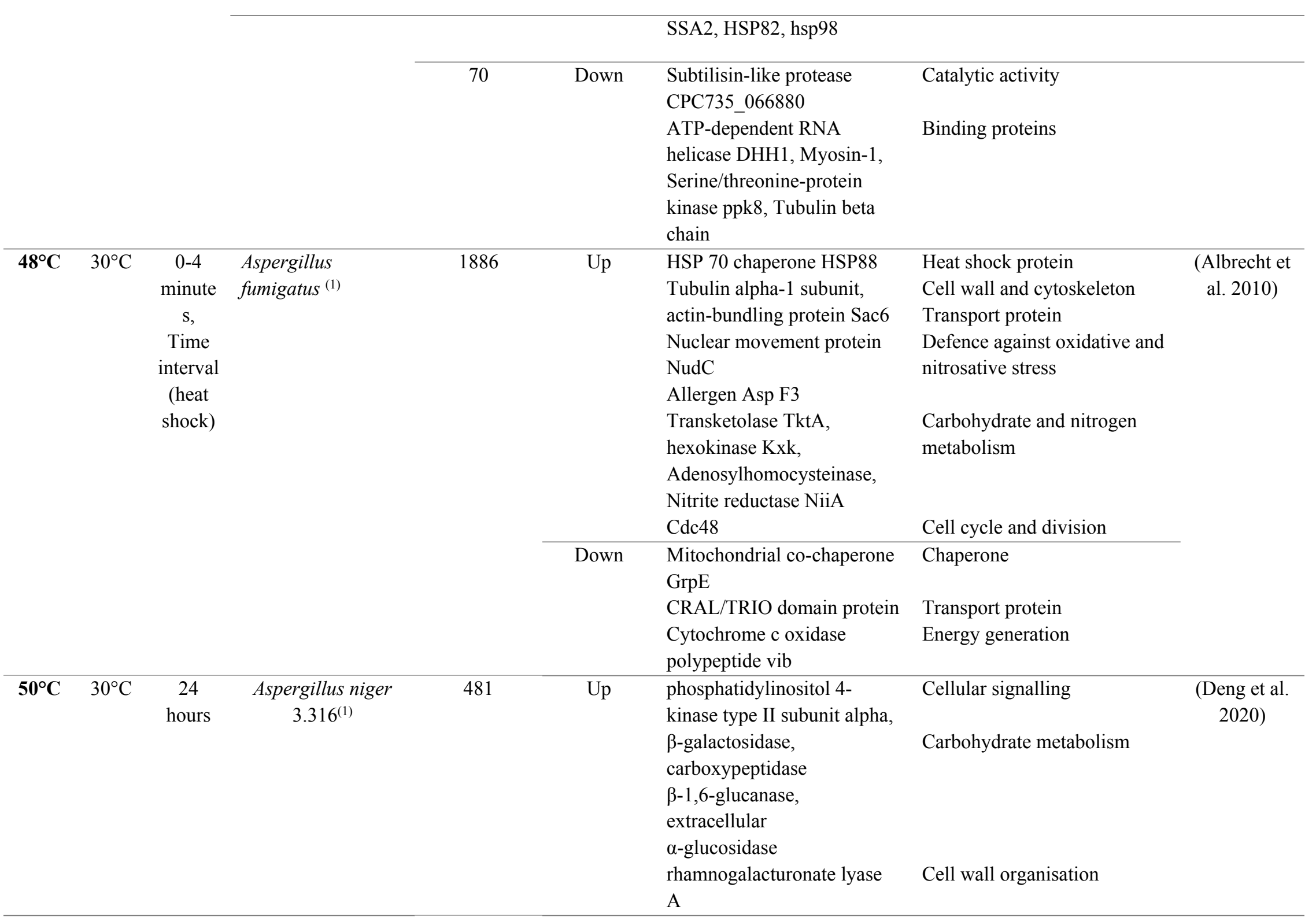


4 Legends and abbrev.

$5 T_{\exp }$-Temperature of exposure, $T_{\mathrm{opt}}-$ Temperature of optimal growth

6 Proteomic profiling approaches.

7 (1) - Gel- free methods

8 (2) - Gel-based method

$9 *$ - Non-conclusive remarks (no proteins identification involved) 


\section{Table 2 (on next page)}

Studies on fungal proteomic profiling in response to low temperature stress (published from 2008-2020).

* - Non-conclusive remarks (no proteins identification involved)

** $-45^{\circ} \mathrm{C}$ is not the optimal growth temperature for E. dermatitidis. However, it is one of the experimental temperature stress (high temperature stress) 
1 Table 2: Studies on fungal proteomic profiling in response to low temperature stress (published from 2008-2020)

\begin{tabular}{|c|c|c|c|c|c|c|c|c|}
\hline $\begin{array}{l}\mathbf{T}_{\exp } \\
\left({ }^{\circ} \mathrm{C}\right)\end{array}$ & $\begin{array}{l}\mathbf{T}_{\text {opt }} \\
\left({ }^{\circ} \mathbf{C}\right)\end{array}$ & Time & Species & $\begin{array}{l}\text { \# no. of } \\
\text { proteins }\end{array}$ & & Proteins identified & Pathways/functions involved & Refs. \\
\hline $1^{\circ} \mathrm{C}$ & $15^{\circ} \mathrm{C}$ & 1 week & F. endolithicus & 466 & - & $\begin{array}{l}\text { Increased no. of protein spots } \\
(41)\end{array}$ & $\begin{array}{l}\text { *Increased in high molecular weight spots } \\
\text { (range from } 70 \text { to } 170 \mathrm{kDa} \text { ), suggesting } \\
\text { production of cold-acclimation proteins }\end{array}$ & $\begin{array}{l}\text { (Tesei } \\
\text { et al. } \\
\text { 2012) }\end{array}$ \\
\hline \multirow[t]{3}{*}{$1^{\circ} \mathrm{C}$} & $28^{\circ} \mathrm{C}$ & 1 week & E. jeanselmei & 387 & - & $\begin{array}{l}\text { Increased no. of protein spots } \\
\text { (5) }\end{array}$ & $\begin{array}{l}\text { *Changes in expression patterns (spots with } \\
\text { MW of } 25-100 \mathrm{kDa} \text { ) }\end{array}$ & \\
\hline & & & C. perforans & 494 & & $\begin{array}{l}\text { Increased no. of protein spots } \\
(169)\end{array}$ & $\begin{array}{l}\text { *exhibited high molecular weight spots } \\
\text { (range from } 70 \text { to } 170 \mathrm{kDa} \text { ), suggesting }\end{array}$ & \\
\hline & & & $\begin{array}{l}P . \\
\text { chrysogenum }\end{array}$ & 358 & & $\begin{array}{l}\text { Decreased no. of protein spots } \\
\text { (23) }\end{array}$ & $\begin{array}{l}\text { *production of cold-acclimation proteins } \\
\text { slight decreased indicates downregulation } \\
\text { of metabolic activity }\end{array}$ & \\
\hline \multirow[t]{11}{*}{$1^{\circ} \mathrm{C}$} & $37^{\circ} \mathrm{C}$ & 1 week & E. dermatitidis & 1700 & Up & 14-3-3 family proteins & Signalling proteins & (Tesei \\
\hline & & & & & & Minor allergen Alt a7 & Small allergen molecules & et al. \\
\hline & & & & & & Nucleoside diphosphate kinase & ATP production pathway & 2015) \\
\hline & & & & & & $\begin{array}{l}\text { Glyceraldehyde-3-phosphate } \\
\text { dehydrogenase }\end{array}$ & Glycolytic pathway & \\
\hline & & & & & Down & Acetyl-coenzyme A & Acetate metabolism & \\
\hline & & & & & & synthetase & Alcohol metabolism & \\
\hline & & & & & & Alcohol oxidase & Aldehyde metabolism & \\
\hline & & & & & & Aldehyde dehydrogenase & Gluconeogenesis & \\
\hline & & & & & & Phosphoenol pyruvate & & \\
\hline & & & & & & carboxykinase $[\mathrm{ATP}]$ & Pyruvate metabolism & \\
\hline & & & & & & Malate synthase, glyoxysomal & & \\
\hline \multirow[t]{7}{*}{$1^{\circ} \mathrm{C}$} & $45^{\circ} C^{* *}$ & 1 week & E. dermatitidis & 1700 & Up & 14-3-3 family proteins & Signalling proteins & \\
\hline & & & & & & Acetyl-coenzyme A & Acetate metabolism & \\
\hline & & & & & & synthetase & Small allergen molecules & \\
\hline & & & & & & Minor allergen Alt a7 & ATP production pathway & \\
\hline & & & & & & Nucleoside diphosphate kinase & Glycolytic pathway & \\
\hline & & & & & & $\begin{array}{l}\text { Glyceraldehyde-3-phosphate } \\
\text { dehydrogenase } \\
\text { Hsp30 }\end{array}$ & Heat shock proteins & \\
\hline & & & & & Down & Alcohol oxidase & Alcohol metabolism & \\
\hline
\end{tabular}




\begin{tabular}{|c|c|c|c|c|c|c|c|c|}
\hline & & & & & & Aldehyde dehydrogenase & Aldehyde metabolism & \\
\hline & & & & & & $\begin{array}{l}\text { Phosphoenol pyruvate } \\
\text { carboxykinase }[\mathrm{ATP}]\end{array}$ & Gluconeogenesis & \\
\hline & & & & & & Beta-lactamase & Antibiotic resistance proteins & \\
\hline & & & & & & Hsp70-like protein & Heat shock proteins & \\
\hline \multirow[t]{4}{*}{$4^{\circ} \mathrm{C}$} & $12^{\circ} \mathrm{C}$ & NA & $M$ & 1673 & Up & GLNA & Amino acid metabolism & (Su et \\
\hline & & & psychrophila & & & MPSY protein & MFS transporter & al. \\
\hline & & & & & Down & $\begin{array}{l}\text { citrate synthase and LSC2 } \\
\text { proteins }\end{array}$ & TCA cycle & 2016) \\
\hline & & & & & & PDC & Glycolysis & \\
\hline \multirow{6}{*}{$\begin{array}{c}12- \\
15^{\circ} \mathrm{C}\end{array}$} & 23- & 2 & Flammulina & 1198 & Up & Trehalase (Fragment) & Trehalose metabolism & (Liu et \\
\hline & $25^{\circ} \mathrm{C}$ & weeks & velutipes & & & Proteasome subunit $\beta$ type & Proteosome pathway & $\begin{array}{c}\text { al. } \\
2017)\end{array}$ \\
\hline & & & & & Down & 60s ribosomal protein & Heat shock proteins & \\
\hline & & & & & & $\begin{array}{l}\text { Acetylornithine } \\
\text { aminotransferase }\end{array}$ & Urea cycle & \\
\hline & & & & & & $\begin{array}{l}\text { Glutathione-disulfide } \\
\text { reductase }\end{array}$ & Oxidative stress pathway & \\
\hline & & & & & & Adenylosuccinate synthetase 1 & Purine biosynthesis & \\
\hline \multirow[t]{7}{*}{$\begin{array}{c}12- \\
15^{\circ} \mathrm{C}\end{array}$} & $\begin{array}{c}23- \\
25^{\circ} \mathrm{C}\end{array}$ & 3 days & $\begin{array}{l}\text { Flammulina } \\
\text { velutipes }\end{array}$ & 1198 & Up & $\begin{array}{l}\text { Heat shock cognate } 70 \\
\text { Catalase }\end{array}$ & $\begin{array}{l}\text { Heat shock proteins } \\
\text { Catalytic enzymes }\end{array}$ & \\
\hline & & & & & Down & Mitochondrial cytochrome & Electron transport chain & \\
\hline & & & & & & T-complex protein eta subunit & Chaperonins & \\
\hline & & & & & & (Tcp-1-eta) Serine & Serine metabolism & \\
\hline & & & & & & hydroxymethyltransferase & & \\
\hline & & & & & & Transketolase & Pentose phosphate pathway & \\
\hline & & & & & & $\begin{array}{l}\text { Methylmalonate-semialdehyde } \\
\text { dehydrogenase }\end{array}$ & Amino acid metabolism & \\
\hline \multirow[t]{6}{*}{$15^{\circ} \mathrm{C}$} & $30^{\circ} \mathrm{C}$ & 24 & Mortierella & 1800 & Up & fructose-bisphosphate aldolase & Glycolytic pathway & (Hu et \\
\hline & & hours & isabellina & & & cytochrome c oxidase & Electron transport & al. \\
\hline & & & M6-22 & & & polypeptide $5 \mathrm{~B}$ & ATP production & 2016) \\
\hline & & & & & & $\begin{array}{l}\text { ATP synthase subunit } \beta \text {, ATP } \\
\text { synthase } \delta \text { subunit }\end{array}$ & & \\
\hline & & & & & & E3 ubiquitinprotein ligase & Ubiquitin-proteasome pathway & \\
\hline & & & & & & BRE1, and histone & & \\
\hline
\end{tabular}


acetyltransferase GCN5

$2 *-$ Non-conclusive remarks (no proteins identification involved)

$3 * *-45^{\circ} \mathrm{C}$ is not the optimal growth temperature for E. dermatitidis. However, it is one of the experimental temperature stress (high

4 temperature stress) 